omeprazole has not been shown to cause any changes in endocrine cell density, ${ }^{16}$ but further studies are needed to elucidate the possible consequences of prolonged acid inhibition in man.

We thank Mrs Rigmor Petersen and Mrs Grete Eskesen for secretarial help; the staff of our endoscopy units for their valued support; Mr Kjeld Clemmensen-Rotne, Astra-Gruppen A/S, Albertslund, Denmark, for skilfully monitoring the conduct of the study; and A B Hässle, Mölndal, Sweden, for the study drugs.

\section{References}

1 Gledhill T, Hunt RH. Oesophagitis and hiatus hernia. In: Misiewicz JJ, Pounder RE, Venables CW, eds. Diseases of the gut and pancreas. Oxford: Blackwell, 1987:137-51.

2 Johansson K-E, Boeryd B, Johansson K, Tibbling L. Double-blind crossover study of ranitidine and placebo in gastro-oesophageal reflux disease. Scand $\mathcal{F}$ Gastroenterol 1986;21:769-78.

3 Wesdorp E, Bartelsman J, Pape K, Dekker W, Tytgat GN. Oral cimetidine in reflux esophagitis: a double blind controlled trial. Gastroenterology 1978;74:821-4.

4 Wesdorp ICE, Dekker $W$, Klinkenberg-Knol EC. Treatment of reflux oesophagitis with ranitidine. Gut 1983;24:921-4.
5 Koelz HR, Birchler R, Bretholz A, et al. Healing and relapse of reflux esophagitis during treatment with ranitidine. Gastroenterology 1986;91:1198-205.

6 Clissold SP, Campoli-Richards DM. Omeprazole. A preliminary review of its pharmacodynamic and pharmacokinetic properties, and therapeutic potential in peptic ulcer disease and ZollingerEllison syndrome. Drugs 1986;32:15-47.

7 Walt RP, Gomes M de FA, Word EC, Logan LH, Pounder RE. Effect of daily oral omeprazole on 24 hour intragastric acidity. $\mathrm{Br} M e d ~ f$ 1983;287:12-4.

8 Lauritsen K, Rune SJ, Bytzer P, et al. Effect of omeprazole and cimetidine on duodenal ulcer: a double-blind comparative trial. $N$ Engl F Med 1985;312:958-61.

9 Lauritsen K, Rune SJ, Wulff HR, et al. Effect of omeprazole and cimetidine on prepyloric gastric ulcer: double blind comparative trial. Gut (in press).

10 Bardhan KD, Bianchi Porro G, Bose K, et al. A comparison of two different doses of omeprazole versus ranitidine in treatment of duodenal ulcers. $\mathcal{F}$ Clin Gastroenterol 1986;8:408-13.

11 Schaub N, Meyrick Thomas J, Misiewicz JJ, Lowell D, Trotman IF. Investigation of ranitidine $150 \mathrm{mg}$ bd or $300 \mathrm{mg}$ bd in the treatment of reflux disease. Hepatogastroenterology 1986;33: 208-13.

12 Fleiss JL. Statistical methods for rates and proportions. New York: Wiley, 1981.

13 Klinkenberg-Knol EC, Jansen JMBJ, Festen HPM, Meuwissen SGM, Lamers CBHW. Doubleblind multicentre comparison of omeprazole and ranitidine in the treatment of reflux cesophagitis. Lancet 1987; $: 349-51$.

14 Sonnenberg A, Lepsien G, Müller-Lissner SA, Koelz HR, Siewert JR, Blum AL. When is esophagitis healed? Esophageal endoscopy, histology and function before and after cimetidine treatment. Dig Dis Sci 1982;27:297-301.

15 Langman MJS. Antisecretory drugs and gastric cancer. Br Med f 1985;290:1850-2.

16 Karvonen A-L, Keyrilainen O, Uusitalo A, et al. Effects of omeprazole in duodenal ulcer patients. Scand $\mathcal{F}$ Gastroenterol 1986;21:449-54.

(Accepted 27 October 1987)

\title{
Upper gastrointestinal Kaposi's sarcoma in patients positive for HIV antibody without cutaneous disease
}

\author{
I G BARRISON, S FOSTER, J W HARRIS, A J PINCHING, J G WALKER
}

\begin{abstract}
Six patients with antibodies to the human immunodeficiency virus (HIV) and with persistent gastrointestinal symptoms of HIV infection but without cutaneous lesions of Kaposi's sarcoma underwent endoscopy. Four also underwent barium meal examination. In all six cases small lesions were seen in the stomach at endoscopy, and histological examination of biopsy specimens taken from the lesions confirmed the diagnosis of Kaposi's sarcoma. The barium meal examinations were reported as normal in three patients and showed oesophageal candidiasis in the fourth.

These findings suggest that Kaposi's sarcoma of the upper gastrointestinal tract is common in patients positive for HIV antibody, even those without cutaneous lesions. Endoscopy, with biopsy of suspicious lesions, is necessary to make the diagnosis and is recommended in all HIV antibody positive patients with persistent upper gastrointestinal symptoms.
\end{abstract}

\section{Introduction}

Infection with human immunodeficiency virus (HIV) results in a wide range of opportunistic infections and tumours, the commonest of which is Kaposi's sarcoma. Two studies have suggested that

\footnotetext{
Departments of Gastroenterology, Clinical Immunology, and Genitourinary Medicine, St Mary's Hospital and Medical School, London W2 INY

I G BARRISON, BSC, MRCP, senior medical registrar

S FOSTER, MRCP, senior registrar in genitourinary medicine

J W HARRIS, FRCP, consultant physician in genitourinary medicine

A J PINCHING, DPHIL, FRCP, senior lecturer in clinical immunology

J G WALKER, MD, FRCP, consultant physician and gastroenterologist

Correspondence to: Dr Barrison.
}

gastrointestinal Kaposi's sarcoma is more likely to be present in this group of patients if there is extensive cutaneous disease. ${ }^{12} \mathrm{We}$ describe six patients positive for HIV antibody without cutaneous disease in whom upper gastrointestinal Kaposi's sarcoma was diagnosed after endoscopy for the investigation of persistent symptoms.

\section{Case reports and methods}

In all six patients, all of them men, the presence of HIV infection was diagnosed by a positive competitive enzyme linked immunosorbent assay (ELISA) for the detection of anti-HIV antibodies (Wellcome) and confirmed by a competitive ELISA system (Abbott). Their associated conditions and reasons for performing endoscopy are shown in the table. Endoscopies were performed by IGB using an Olympus $\mathrm{GIF}_{1} \mathrm{~T}_{10}$ fully immersible endoscope. Two to four biopsy specimens were obtained from each lesion using the $5 \mathrm{~mm}$ Olympus biopsy forceps. Cutaneous Kaposi's sarcoma was excluded by at least two clinical examinations by independent observers.

Findings on endoscopy and the results of a barium meal examination (performed in four patients) are shown in the table, and typical endoscopic appearances are shown in the figure. Histological confirmation of the diagnosis of Kaposi's sarcoma was obtained in all six cases. Five of the six patients had oral candidiasis but only three had oesophageal candidiasis. The barium meal examinations were reported as normal in three patients and showed oesophageal candidiasis in the fourth.

\section{Discussion}

These six cases show that upper gastrointestinal Kaposi's sarcoma frequently occurs in HIV antibody positive patients with persistent symptoms in the absence of cutaneous disease. At present the prevalence of gastric Kaposi's sarcoma among HIV antibody positive patients without cutaneous lesions is unknown. We have found lesions in six out of 25 symptomatic patients (26\%) examined to date and in seven out of 13 patients with cutaneous Kaposi's 

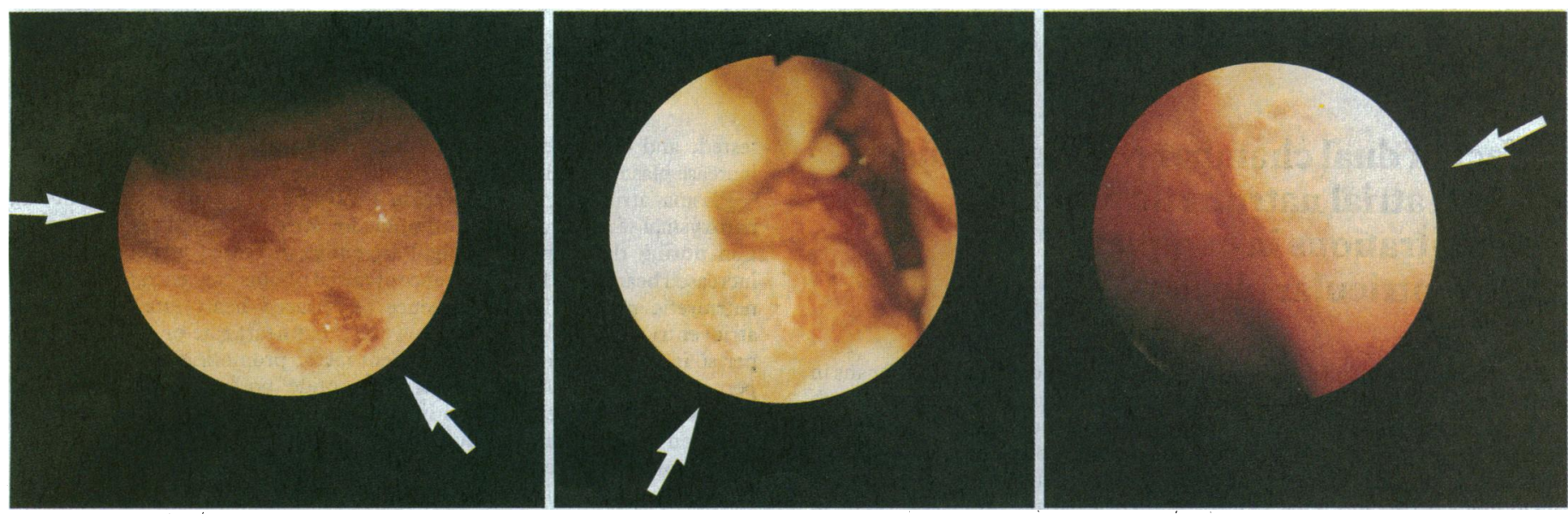

Endoscopic appearances (marked by arrows) in three patients with gastrointestinal Kaposi's sarcoma. Left (case 1): macular lesions in body of stomach; middle (case 4): polypoidal lesion on greater curve of stomach; right (case 5): plaque-like lesion on lesser curve of stomach.

Clinical details of HIV antibody positive patients with gastric Kaposi's sarcoma

\begin{tabular}{|c|c|c|c|c|c|}
\hline Case No & Age and sex & Barium meal & Other HIV associated disease & Indications for endoscopy & Findings on endoscopy \\
\hline 1 & $35 \mathrm{M}$ & & $\begin{array}{l}\text { Chronic hepatitis B carrier, oral } \\
\text { candidiasis, perianal herpes simplex }\end{array}$ & Postprandial epigastric pain & Two small plaques ( $<5 \mathrm{~mm}$ ) in body of stomach \\
\hline 2 & $39 M$ & Normal & $\begin{array}{l}\text { Oral candidiasis, persistent } \\
\text { generalised lymphadenopathy }\end{array}$ & Intractable dysphagia & $\begin{array}{l}\text { Oesophageal candidiasis, multiple small plaques } \\
\text { throughout stomach }\end{array}$ \\
\hline 3 & $29 M$ & Oesophageal candidiasis & Oral candidiasis & Intractable dysphagia & $\begin{array}{l}\text { Oesophageal candidiasis, several small }(<5 \mathrm{~mm}) \text { red } \\
\text { plaques in gastric antrum }\end{array}$ \\
\hline 4 & $37 \mathrm{M}$ & & $\begin{array}{l}\text { Oral candidiasis, persistent } \\
\text { generalised lymphadenopathy }\end{array}$ & Chronic nausea and anorexia & $\begin{array}{l}\text { Oesophageal candidiasis, polypoidal lesions } \\
\text { throughout body and antrum of stomach }\end{array}$ \\
\hline $\begin{array}{l}5 \\
6\end{array}$ & $\begin{array}{l}35 M \\
43 M\end{array}$ & $\begin{array}{l}\text { Normal } \\
\text { Normal }\end{array}$ & $\begin{array}{l}\text { Angiofollicular hyperplasia } \\
\text { Oral candidiasis, perianal herpes } \\
\text { simplex }\end{array}$ & $\begin{array}{l}\text { Weight loss, persistent vomiting } \\
\text { Postprandial epigastric discomfort }\end{array}$ & $\begin{array}{l}\text { Multiple small red plaques in stomach and duodenum } \\
\text { Multiple small red plaques in oesophagus, stomach, } \\
\text { and duodenum }\end{array}$ \\
\hline
\end{tabular}

sarcoma (54\%). Friedman et al reported a prevalence of $40 \%$ in 50 patients with the acquired immune deficiency syndrome (AIDS) and cutaneous Kaposi's sarcoma ${ }^{2}$ and Saltz et al a prevalence of $50 \%$ in 19 similar patients. ${ }^{\prime}$

In two of our four patients the lesions were less than $5 \mathrm{~mm}$ in diameter and could have been misinterpreted as patchy gastritis at endoscopy. Biopsy of all suspicious lesions is necessary in this group of patients. Barium examination of the stomach was reported as normal in three patients with gastric Kaposi's sarcoma, and, although contrast studies are helpful when the classical submucosal filling defects are present, the technique is not very sensitive in detecting macular lesions such as those seen in five of our six patients. There is still some concern about the safety of fibreoptic endoscopy in patients with HIV antibodies-which is unjustified -and some doubts about the diagnostic yield. One study in patients with upper gastrointestinal symptoms and oropharyngeal candidiasis suggested that endoscopy would merely confirm the presence of oesophageal candidiasis. ${ }^{3}$ Five of our six patients had oral candidiasis and the diagnosis of Kaposi's sarcoma would not have been made without endoscopy.

Newer, more efficacious treatments for HIV related diseases are becoming available, and prompt diagnosis of gastrointestinal
Kaposi's sarcoma is clearly desirable from a prognostic and a therapeutic point of view. Symptoms may resolve after chemotherapy and the progression of the Kaposi sarcoma may be delayed. Specific anti-HIV treatments are now available-for instance, the reverse transcriptase inhibitor zidovudine (azidothymidine)-which may influence the clinical course of the disease and therefore increase the importance of making an early and accurate diagnosis. ${ }^{4}$ We therefore recommend endoscopy in all patients with HIV antibodies who have persistent upper gastrointestinal symptoms.

\section{References}

1 Saltz RK, Kurtz RC, Lightdale CJ, et al. Kaposi's sarcoma: gastrointestinal involvement and correlation with skin findings and immunologic function. Dig Dis Sci 1984;29:817-23.

2 Friedman SL, Wright TL, Altman DF. Gastrointestinal Kaposi's sarcoma in patients with acquired immunodeficiency syndrome. Gastroenterology 1985;89:102-8.

3 Tavitian A, Raufman JP, Rosenthal LE. Oral candidiasis as a marker for oesophageal candidiasis in the acquired immunodeficiency syndrome. Ann Interm Med 1986;104:54-5.

4 Fischl MA, Richman D, Grieco MH, et al. The efficacy of azidothymidine (AZT) in the treatment of patients with AIDS and AIDS-related complex. N Engl f Med 1987;317:185-91.

(Accepted 26 October 1987) 